\title{
The 1986 paper by Kanbur and Stiglitz on 'Intergenerational Mobility and Dynastic Inequality'
}

\author{
Gordon Anderson 1
}

Received: 3 February 2016 / Accepted: 16 February 2016 / Published online: 26 July 2016

(C) Springer Science+Business Media New York 2016

There is little need to justify the prescience of this classic. In 2014 Thomas Piketty's book about the ubiquitous rise in 'snapshot' inequality, Capital in the Twenty-First Century, took the world by storm, eliciting an almost immediate riposte from some quarters - that a rise in 'snapshot' inequality was neither here nor there, and that what was important was mobility across generations and equality of opportunity. In response to this, Stiglitz (2015) and Kanbur and Wagstaff (2014) argued that inequality of outcome was important because it would affect inequality of opportunity.

These arguments had been debated and developed in the OECD-hosted High Level Expert Group on the Measurement of Economic and Social Progress, which Stiglitz cochaired and of which Kanbur was a member. The arguments were of course related to the technical results in an unpublished discussion paper by Kanbur and Stiglitz (1986) linking mobility to dynastic inequality which was obviously highly germane to the current debate. That discussion paper arrived on the scene in the early stages of a strand of literature evaluating mobility with explicit intertemporal social welfare functions, linking these to conventional views on what constitutes greater mobility in a society. It was referred to in major surveys of income mobility at the time (Fields and Ok 1999; Maasoumi 1998) and has received many citations elsewhere including in the most recent survey (Jäntti and Jenkins 2015). It is a revised version of the Kanbur and Stiglitz (1986) discussion paper that is published here as a Rediscovered Classic.

Together with papers like those by Atkinson and Bourguignon (1982) and Atkinson (1981a, b), Kanbur and Stiglitz's paper influenced a younger generation of scholars in their work on normative evaluation of income distribution dynamics. In thinking about the elements of the transition matrix in the context of dominance relationships (see Section 2), it was a precursor to the work of Dardanoni (1993) and Lefranc et al. (2009), for example. It was one of the earliest papers to address the idea of persistence of wellbeing status

Gordon Anderson

anderson@ chass.utoronto.ca

1 Department of Economics, University of Toronto, Toronto, Ontario M5S 3G7, Canada 
in the theoretical setting of long-lived dynasties. (It extends the Atkinson (1981a, b) twoperiod analysis to an infinitely lived world). The main result of the paper, echoing Shorrocks (1978), is that lower dynastic inequality is facilitated by transition matrices that are more unlike the identity matrix. A somewhat salutary finding for equal opportunity advocates (and notably ignored by most) is that the equal opportunity transition matrix (i.e. the one with identical rows) is not necessarily one which minimizes dynastic inequality.

The ideas in the paper crystallized during Kanbur's visit to Princeton in 1985-87. There he worked with Stiglitz, who had previously been his doctoral advisor in the late 1970s at Oxford. There, in addition to discussing the doctoral research topics, they exchanged ideas on intertemporal mobility and dynastic inequality, an area of emerging interest to economists in the 1970s. Their joint work appeared as Kanbur and Stiglitz (1986). Although a journal did invite a revise and resubmit, the exigencies of the time meant that the project was shelved and never saw the light of day in a journal (Kanbur went to the World Bank and Stiglitz joined the Clinton Administration). Given the developments in 2014, Kanbur and Stigilitz have revisited the old paper, updated the references (to make the paper directly relevant to current debates and to recognize the technical work that had been done since then), fixed some elements of the technical detail, and changed the title to 'Dynastic inequality, mobility and equality of opportunity' to take on board a key element of the discourse to which the paper spoke. The new paper was issued as CEPR Working Paper 10542 in April 2015 and is presented here in its revised form.

\section{References}

Atkinson, A.B.: On intergenerational income mobility in Britain. J. Post Keynesian Econ. 3, 194-218 (1981a) Atkinson, A.B.: The measurement of economic mobility. In: Eigjelshoven, P.J., van Gemerden, L.J. (eds.) Inkomensverdeling en openbare financien - Essays in Honour of Jan Pen. Het Spectrum, Utrecht (1981b). 9-24. Also published in: A. B. Atkinson (ed.), Social Justice and Public Policy. Hemel Hempstead, Wheatsheaf Books, 61-75 (1983).

Atkinson, A.B., Bourguignon, F.: The comparison of multi-dimensional distributions of economic status. Rev. Econ. Stud. 49, 183-201 (1982)

Dardanoni, V.: Measuring social mobility. J. Econ. Theory 61, 372-394 (1993)

Fields, G.S., Ok, E.A.: The measurement of income mobility: An introduction to the literature. In: Silber, J. (ed.) Handbook on Income Inequality Measurement, pp. 557-596. Kluwer Academic Publishers, Norwell (1999)

Jäntti, M., Jenkins, S.P.: Income mobility. In: Atkinson, A.B., Bourguignon, F. (eds.) Handbook of Income Distribution, vol. 2A, pp. 807-935. Elsevier, Oxford (2015)

Kanbur, S.M.R., Stiglitz, J.E.: Intergenerational mobility and dynastic inequality. Research memorandum 324, Econometric Research Program, Princeton. University, Princeton (1986). http://www.princeton. edu/ erp/ERParchives/archivepdfs/M324.pdf

Kanbur, R., Wagstaff, A.: How useful is inequality of opportunity as a policy construct? Policy Research Working Paper 6980. World Bank, Washington (2014)

Lefranc, A., Pistolesi, N., Trannoy, A.: Equality of opportunity and luck: definitions and testable conditions, with an application to income in France. J. Public Econ. 93(11-12), 1189-1207 (2009)

Maasoumi, E.: On mobility. In: Giles, D., Ullah, A. (eds.) Handbook of Applied Economic Statistics, pp. 119175. Marcel Dekker, New York (1998)

Shorrocks, A.F.: The measurement of mobility. Econometrica 46, 1013-1024 (1978)

Stiglitz, J.E.: The great divide: Unequal Societies and What We Can Do About Them. W.W. Norton, New York (2015) 